\begin{tabular}{|l|l|l||}
\hline \multicolumn{2}{|c|}{ PublisherInfo } \\
\hline \hline PublisherName & $:$ & BioMed Central \\
\hline \hline PublisherLocation & $:$ & London \\
\hline \hline PublisherImprintName & $:$ & BioMed Central \\
\hline \hline
\end{tabular}

\title{
Junk DNA controls embryos
}

\begin{tabular}{|l|l|l||}
\hline \multicolumn{2}{|c|}{ ArticleInfo } \\
\hline \hline ArticleID & $:$ & 5009 \\
\hline \hline ArticleDOI & $:$ & $10.1186 /$ gb-spotlight-20041012-01 \\
\hline \hline ArticleCitationID & $:$ & spotlight-20041012-01 \\
\hline \hline ArticleSequenceNumber & $:$ & 72 \\
\hline \hline ArticleCategory & $:$ & Research news \\
\hline \hline ArticleFirstPage & $:$ & 1 \\
\hline \hline ArticleLastPage & $:$ & 3 \\
\hline \hline & & RegistrationDate : 2004-10-12 \\
ArticleHistory & $:$ & OnlineDate \\
\hline \hline ArticleCopyright & $:$ & BioMed Central Ltd2004-10-12 \\
\hline \hline ArticleGrants & $:$ & \\
\hline \hline ArticleContext & $:$ & 130595511 \\
\hline \hline
\end{tabular}


Email: cathy.holding@absw.org.uk

Transposable elements (TEs) appear to govern the transition from oocyte to embryo in mice, according to a study in Developmental Cell this week. The paper questions the idea that some of the numerous repetitive TEs present in the genome are just "junk" (Dev Cell 2004, 7:597-606).

Barbara B. Knowles, from the Jackson Laboratory at Bar Harbor, Maine, and her group showed that the maternal transcriptome in mouse eggs and very early cleavage embryos contains an unusually high level of TEs that act as promoters and first exons for numerous RNA molecules, revealing a role as stage-specific alternative promoters for a number of host genes.

"We realized that in one of the two forms [of a gene under study], there was a retrotransposon at this unique time [the egg/embryo transition] integrated in front of it," Knowles told us. The researchers found that the first 20 amino acids of the gene consisted of not only the controlling element of the retrotransposon but also part of the retrotransposon that was a part of this gene, at its 5 ' end, which suggested that the TE could change the function of the gene.

To determine the overall pattern of TE expression in full-grown oocytes and preimplantation embryos, the team analyzed the number of repetitive element-expressed sequence tags in cDNA libraries from oocytes and 2-cell stage embryos and blastocysts. "We found that the retrotransposons actually do... regulate the expression of a number of different kinds of genes in the genome," Knowles said.

Normal repressive chromatin structure for these loci is established sequentially during the oocyte-toembryo transition and preimplantation stages, according to the authors.

Linheng Li, at the Stowers Institute for Medical Research in Missouri, said that the findings may be interesting in relation to chromatin opening and the reprogramming occurring then. During nuclear reprogramming after fertilization, the chromosome is wide open because all previous imprints are wiped out.

"In this case, it seems like a lot of genes are just randomly expressed," Li told us. "My point is, either TE expression is involved in reprogramming or it is a reflection of the reprogramming that is going on." Li was not involved in the study.

"It's an intriguing mechanism; the question is what does it mean?" said Janet Rossant, a professor at the University of Toronto not involved in the study. "Why does the embryo do that? What's the significance to the embryo? I don't think any of those questions are really answered at this point."

Knowles said she thinks the TEs regulate the expression of genes purely as a byproduct of where they are integrated: "I think that they can randomly integrate at a particular time, and then if they're detrimental, then that's the end of the egg, or the embryo. And if they're beneficial, or neutral, it's possible that they may just stay there forever." Those that the team looked at must have been evolutionarily conserved because some of them can be found in the rat genome, said Knowles.

"I think a lot of 'junk DNA' has a function, and in a weird way it's controlling gene expression," Knowles said. 


\section{References}

1. Developmental Cell, [http://www.developmentalcell.com/]

2. Barbara B. Knowles, [http://www.jax.org/staff/barbara_knowles.html]

3. Linheng Li, [http://www.stowers-institute.org/labs/lilab.asp]

4. Janet Rossant, [http://www.mshri.on.ca/rossant/index.html]

This PDF file was created after publication. 